\title{
Kromium serum dan asupan mikromineral pada penyandang diabetes tipe 2
}

Chromium serum and dietary micromineral intake among type II diabetic patients

\author{
Ni Ketut Sutiari ${ }^{1}$, Rimbawan ${ }^{2}$, Clara Meliyanti Kusharto ${ }^{2}$, Purwantyastuti Ascobat ${ }^{3}$, Adi Teruna Effendi ${ }^{4}$
}

${ }^{1}$ Program Studi Ilmu Gizi Manusia, Sekolah Pascasarjana Institut Pertanian Bogor

${ }^{2}$ Departemen Gizi Masyarakat, Fakultas Ekologi Manusia Institut Pertanian Bogor

${ }^{3}$ Departemen Farmakologi, Fakultas Kedokteran Universitas Indonesia

${ }^{4}$ Rumah Sakit Pertamedika Sentul City Bogor

\begin{abstract}
Background: Status of minerals such as zinc, magnesium and chromium among diabetic patients are considered lower than nondiabetic peoples, both in the serum and intake. Some reviews shows that those minerals contribute to carbohydrate metabolism among diabetic patients. Objective: This study aims to explore intake of zinc, magnesium and chromium among DMT2 in Denpasar. Method: This is a cross-sectional analytic study. Population were all (70) DMT2 patients registered at Chronic Disease Service (Prolanis) at two Primary Health Care (PHC) Denpasar Utara III PHC and Denpasar Timur I PHC. Sample for the study was DMT2 patients and non-diabetic people age 50-70 years reside in Denpasar city. DMT2 patients were randomly selected with simple random technique, while non-diabetic peoples were non-randomly selected. Level of serum chromium was measured by $A A S$ method, whereas microminerals intake were collected by recall and SQ-FFQ method. Data was analyzed descriptively and differences were tested with two independent t-test at $95 \%$ confidence level. Results: The mean of serum chromium DMT2 and non-diabetic were $0.044 \mathrm{mg} / \mathrm{L}$ and $0.094 \mathrm{mg} / \mathrm{L}$ respectively. The mean $\pm S E M$ magnesium (DMT2 316.1 $22.4 \mathrm{mg} /$ day; non-diabetic $211.0 \pm 33.5 \mathrm{mg} /$ day), zinc intake was (DMT2 8.4 $\pm 0.7 \mathrm{mg} /$ day; non-diabetic $6.2 \pm 0.8 \mathrm{mg} /$ day), and chromium (DMT2 $10.8 \pm 1.3 \mu \mathrm{g} /$ day; non-diabetic 8.7 $\pm 0.9 \mu \mathrm{g} /$ day). Significant difference was found on magnesium intake ( $p=0.01)$. Conclusion: The study showed that serum chromium in DMT2 patients is lower than nondiabetic. The magnesium intake among DMT2 is higher as compare to nondiabetic, while zinc and chromium intake are not different in both group.
\end{abstract}

KEY WORDS: magnesium; non-diabetic; serum chromium; type 2 diabetes; zinc

\begin{abstract}
ABSTRAK
Latar belakang: Status mineral zink, magnesium, dan kromium pada penyandang diabetes diduga sangat rendah dibandingkan dengan nondiabetes, baik dalam serum maupun konsumsi makannya. Beberapa hasil review menyebutkan bahwa jenis mineral tersebut dapat membantu metabolisme karbohidrat pada penyandang diabetes. Tujuan: Menganalisis asupan gizi zink, magnesium, dan kromium penyandang diabetes tipe 2 (DMT2) di Kota Denpasar. Metode: Jenis penelitian ini adalah studi cross sectional analitik. Populasi merupakan seluruh penyandang DMT2 yang terdaftar dalam Program Pelayanan Penyakit Kronis (Prolanis, khusus penyakit diabetes) di Puskesmas III Denpasar Utara dan Puskesmas I Denpasar Timur berjumlah 70 orang. Sampel penelitian adalah penyandang DMT2 dan nondiabetes yang berusia 50-70 tahun, berdomisili di Denpasar. Penarikan subjek DMT2 dengan simple random sampling sedangkan nondiabetes menggunakan nonrandom sampling. Kromium serum diperiksa dengan metode AAS sedangkan asupan mikromineral dikumpulkan dengan metode recall dan SQ-FFQ. Analisis data dilakukan secara deskriptif (univariat) dan uji t-two independent dengan tingkat ketelitian 95\%. Hasil: Rerata kadar kromium serum DMT2 dan nondiabetes masing-masing 0,044 mg/L dan 0,094 mg/L. Rerata \pm SEM asupan magnesium (DMT2 316,1 $\pm 22,4 \mathrm{mg} /$ hari; nondiabetes 211,0 $\pm 33,5$ $\mathrm{mg} /$ hari), zink (DMT2 8,4 $\pm 0,7 \mathrm{mg} /$ hari; nondiabetes $6,2 \pm 0,8 \mathrm{mg} / \mathrm{hari}$ ), dan kromium (DMT2 10,8 $\pm 1,3 \mu \mathrm{g} / \mathrm{hari}$; nondiabetes $8,7 \pm 0,9$ $\mu \mathrm{g} /$ hari) menunjukkan adanya perbedaan signifikan pada asupan magnesium $(\mathrm{p}=0,01)$ antara diabetes dan nondiabetes. Simpulan: Kromium serum pada DMT2 lebih rendah daripada nilai kromium serum nondiabetes. Asupan magnesium pada penyandang DMT2 lebih tinggi dibandingkan dengan nondiabetes, sedangkan asupan zink dan kromium pada kedua kelompok tidak berbeda.
\end{abstract}

KATA KUNCI: magnesium; nondiabetes; kromium serum; diabetes tipe 2; zink

Korespondensi: Ni Ketut Sutiari, Program Studi Kesehatan Masyarakat, Fakultas Kedokteran Universitas Udayana, Jl. PB Sudirman, Denpasar, Bali 80232, Indonesia, e-mail:ksutiari@yahoo.com 


\section{PENDAHULUAN}

Salah satu pilar dalam konsensus pengobatan dan pencegahan diabetes mellitus tipe 2 (DMT2) yaitu memberikan terapi gizi medis (medical nutrition therapy). Terapi gizi bagi DMT2 ditekankan pada jadwal pemberian makan, jenis makanan/bahan makan yang baik bagi DMT2, dan perhatian pada porsi makan serta menjaga keseimbangan zat gizi makro dan mikro $(1,2)$. Peran beberapa trace mineral dalam penelitian klinis sedang berkembang pada beberapa dekade terakhir. Beberapa mineral tersebut akan mempunyai peran esensial dalam beberapa proses metabolik tubuh manusia apabila konsentrasi mineral dalam tubuh normal (3). Penelitian sebelumnya melaporkan bahwa ada potensi aksi insulin pada kasus diabetes dengan keberadaan mikromineral atau trace mineral, seperti kromium, magnesium, vanadium, zink, molibdenum, mangan, dan selenium (4). Kekurangan mikromineral diduga dapat menyebabkan penyakit kronis seperti diabetes atau sebaliknya penyakit kronis yang menyebabkan kekurangan mikromineral tertentu, kedua pernyataan ini masih belum jelas (5).

Hasil penelitian di Jepang menunjukkan bahwa sebagian besar (>50\%) penyandang DMT2 mempunyai asupan magnesium dan zink lebih rendah dari nilai estimated average requirement (EAR) (6). Namun, penelitian di Swiss melaporkan bahwa asupan magnesium antara kelompok diabetes dan kontrol tidak berbeda, bahkan asupan magnesium kedua kelompok tersebut melebihi nilai standar kecukupan gizi magnesium Swiss (7). Manfaat yang lainnya, yaitu kecukupan zink dari makanan ternyata mampu menurunkan risiko DMT2 pada wanita $(8,9)$.

Penelitian mengenai asupan gizi mineral pada penyandang DMT2 di negara-negara lain untuk saat ini masih jarang dan yang terlaporkan merupakan hasil penelitian lebih dari 10 tahun. Di Indonesia, penelitian mengenai status mikromineral dalam makanan dan darah pada penyandang DMT2 juga belum banyak terlaporkan. Dua tahun yang lalu, terdapat studi asupan magnesium yang dihubungkan dengan kadar glukosa darah pasien DMT2 rawat jalan di Rumah Sakit Umum Daerah (RSUD) Al-Ihsan Jawa Barat. Studi ini menemukan bahwa semakin tinggi asupan magnesium maka semakin rendah kadar glukosa darah puasa pasien sehingga pasien DMT2 disarankan untuk memperhatikan kecukupan asupan magnesium mereka (10). Dengan demikian, penelitian ini bertujuan untuk memberikan profil kromium serum serta asupan magnesium, zinc, dan kromium yang dianalisis dari jenis dan porsi makan yang dikonsumsi penyandang DMT2.

\section{BAHAN DAN METODE}

Penelitian ini merupakan studi cross-sectional analitik yang dilaksanakan pada dua Puskesmas di Kota Denpasar, yaitu Puskesmas III Denpasar Utara dan Puskesmas I Denpasar Timur pada bulan Juli - Oktober tahun 2015. Pemilihan lokasi penelitian dilakukan dengan pertimbangan bahwa pada kedua puskesmas tersebut terdapat penyandang DMT2 dan nondiabetes dan akses menuju lokasi terjangkau.

Populasi target adalah penyandang DMT2 yang terdaftar dalam Program Pelayanan Penyakit Kronis (Prolanis, khusus penyakit diabetes), masyarakat pengunjung puskesmas, dan petugas puskesmas yang dinyatakan tidak menyandang diabetes berdasarkan hasil pemeriksaan dokter puskesmas, berusia 50-70 tahun serta berdomisili di Kota Denpasar. Jumlah populasi target penyandang DMT2 sebesar 70 orang sedangkan populasi target nondiabetes sebesar 80 orang. Subjek penelitian merupakan bagian dari populasi yaitu penyandang DMT2 dan nondiabetes. Kriteria inklusi yaitu laki-laki maupun wanita, berusia 50-70 tahun, berdomisili di Kota Denpasar, dan bersedia menjadi subjek penelitian dengan menandatangani informed consent. Kriteria eksklusi adalah penyandang DMT2 yang sedang mengalami komplikasi kronis saat penelitian berdasarkan laporan medis dokter, memiliki pendengaran dan komunikasi yang tidak bagus, dan masyarakat nondiabetes yang sedang sakit berdasarkan hasil pemeriksaan dokter. Informed consent adalah formulir yang terdiri dari naskah penjelas yang mengandung penjelasan mengenai cara pengumpulan data, kemungkinan ada atau tidaknya efek samping saat pengambilan sampel darah, petunjuk yang dapat dihubungi apabila terjadi sesuatu terkait dengan kesehatan subjek, dan lembar persetujuan yang berisi pernyataan bahwa subjek menyetujui sebagai subjek dalam penelitian.

Besar sampel dihitung berdasarkan rumus besar sampel untuk data berskala kontinyu dan alokasi 
proporsional populasi (11). Berdasarkan survei awal terhadap populasi DMT2 dan nondiabetes diketahui proporsi populasi DMT2 (w1) sebesar 0,466 dan proporsi populasi nondiabetes (w2) sebesar 0,50 ; tingkat kepercayaan 95\%; nilai presisi antarkelompok sebesar 0,55 ; dan standar deviasi (SD) glukosa darah puasa (GDP) DMT2 sebesar 2,7 mmol/L dan SD nondiabetes sebesar $0,1 \mathrm{mmol} / \mathrm{L}$ (12). Dari rumus besar sampel didapatkan jumlah sampel minimal sebanyak 43 orang. Subjek penelitian yang telah memenuhi kriteria dipilih secara simple random sampling sedangkan subjek nondiabetes dipilih secara nonrandom sampling.

Variabel yang diteliti yaitu variabel berskala kontinyu yang meliputi variabel status gizi berdasarkan nilai indeks massa tubuh (IMT) dan lingkar pinggang (LP), kadar glukosa darah puasa (GDP), kadar kromium serum, asupan magnesium, asupan zink, dan asupan kromium. Status gizi subjek menurut IMT diperoleh melalui penimbangan berat badan (BB) dan pengukuran tinggi badan (TB). Penimbangan BB menggunakan timbangan digital Camry dengan ketelitian $0,1 \mathrm{~kg}$ sedangkan pengukuran TB menggunakan mikrotoise dengan ketelitian $0,1 \mathrm{~cm}$. Status gizi subjek menurut nilai LP diperoleh melalui pengukuran LP menggunakan pita meter dengan ketelitian $0,1 \mathrm{~cm}$.

Parameter biokimia darah diperiksa dengan memakai sampel darah vena sebanyak $5 \mathrm{cc}$ yang diambil oleh petugas Laboratorium Kesehatan Daerah Provinsi Bali pada pukul 08.00-10.00 WITA. Satu hari sebelum pengambilan darah, subjek diminta berpuasa sekitar 10 jam. Kadar GDP diperiksa dengan metode GOD-PAP enzymatic colorimetric di Laboratorium Kesehatan Daerah Provinsi Bali sedangkan kromium serum diperiksa dengan metode Atomic Absorbance Spectrophotometric (AAS) di Laboratorium Kimia Terpadu Universitas Udayana Denpasar.

Data asupan makanan dikumpulkan dengan metode recall $2 \times 24$ jam secara berturut-turut sedangkan kebiasaan makan subjek satu bulan terakhir dikumpulkan dengan metode Semi Quantitative Food Frequency Questionnaire (SQ-FFQ) yang dilakukan oleh peneliti dan dibantu oleh enumerator yaitu mahasiswa lulusan Jurusan Gizi Poltekes Kemenkes Denpasar. Asupan makan dianalisis dengan software Nutrisurvey 2007 for windows untuk memperoleh nilai kandungan magnesium dan zink masing- masing jenis bahan makanan sehingga diperoleh nilai total asupan magnesium dan zink per hari. Nilai kandungan kromium dari asupan makanan dianalisis secara manual dengan mengacu pada beberapa sumber bahan makanan dalam Daftar Komposisi Bahan Makanan (DKBM) yang dikeluarkan oleh Ministry of Education, Culture, Sports, Science and Technology Jepang dan diperoleh total asupan kromium per hari. Asupan mineral dikategorikan menjadi 2 yaitu cukup apabila tingkat kecukupan mineral $\geq 77 \%$ dan defisit (kurang) apabila tingkat kecukupan mineral $<77 \%$ (13). Tingkat kecukupan mineral dihitung dengan membagi antara asupan mineral dengan kecukupan mineral sesuai dengan Angka Kecukupan Gizi yang Dianjurkan (AKG) Indonesia tahun 2014.

Uji normalitas dilakukan pada data penelitian ini untuk menilai data berdistribusi normal atau tidak. Data disajikan dalam bentuk univariat (rerata, standar deviasi/ $\mathrm{SD}$, standar error mean/SEM, dan persentase). Analisis statistik yang digunakan adalah uji t-two independent samples jika data terdistribusi normal serta uji MannWhitney apabila data tidak berdistribusi normal dengan tujuan untuk menguji kemaknaan perbedaan 2 rerata terhadap 2 kelompok. Protokol penelitian ini termasuk juga informed consent yang dipakai dalam penelitian telah disetuji oleh Komisi Etik Penelitian dan Pengembangan Kesehatan Fakultas Kedokteran Universitas Udayana dan Rumah Sakit Umum Pusat Sanglah (RSUP) Denpasar dengan dikeluarkannya surat keterangan lolos kaji etik (ethical clearance) dengan Nomor: 1439/UN.14.2/ Litbang/2015 tanggal 30 Juli 2015.

\section{HASIL}

\section{Status gizi dan profil biokimia darah subjek penelitian}

Selama penelitian berlangsung, terdapat 43 subjek yang mengikuti seluruh tahap penelitian yang terdiri dari 16 subjek nondiabetes dan 27 subjek DMT2, sesuai dengan besar sampel minimal penelitian ini. Nilai rerata umur kelompok subjek DMT2 lebih tinggi signifikan $(\mathrm{p}=0,016)$ dibandingkan dengan kelompok nondiabetes, demikian juga dengan kadar gula darah puasa (GDP) $(\mathrm{p}=0,04)$ dan kromium serum $(\mathrm{p}=0,000)$. Nilai rerata IMT dan lingkar pinggang (LP) antara kelompok subjek DMT2 dengan 
Tabel 1. Status gizi dan parameter biokimia darah DMT2 dan nondiabetes ${ }^{1}$

\begin{tabular}{lccc}
\hline \multicolumn{1}{c}{ Variabel } & $\begin{array}{c}\text { Kelompok } \\
\text { nondiabetes } \\
(\mathbf{n}=\mathbf{1 6})\end{array}$ & $\begin{array}{c}\text { Kelompok } \\
\text { DMT2 } \\
(\mathbf{n}=\mathbf{2 7})\end{array}$ & $\mathbf{p}^{5}$ \\
\hline Umur (tahun) & $55,6 \pm 6,6$ & $60,3 \pm 5,6$ & $0,016^{*}$ \\
$\mathrm{IMT}\left(\mathrm{kg} / \mathrm{m}^{2}\right)^{2}$ & $24,4 \pm 2,2$ & $23,7 \pm 2,9$ & 0,382 \\
$\mathrm{LP}(\mathrm{cm})^{3}$ & $82,0 \pm 7,4$ & $85,8 \pm 8,1$ & 0,127 \\
$\quad$ Laki-laki & $86,7 \pm 5,8$ & $89,1 \pm 7,8$ & 0,496 \\
$\quad$ Wanita & $77,2 \pm 5,5$ & $83,9 \pm 7,9$ & $0,042 *$ \\
GDP $(\mathrm{mg} / \mathrm{dl})^{4}$ & $100,3 \pm 16,0$ & $133,9 \pm 61,8$ & $0,040 *$ \\
Kromium serum \\
(mg/L)
\end{tabular}

nondiabetes tidak berbeda signifikan $(\mathrm{p}=0,127)$, kecuali nilai LP kelompok subjek wanita DMT2 lebih besar daripada subjek wanita nondiabetes $(\mathrm{p}<0,05)$ (Tabel 1).

\section{Asupan mikromineral}

Tabel 2 menyajikan profil asupan dan tingkat kecukupan magnesium, zink, dan kromium. Berdasarkan hasil recall 2x24 jam diketahui bahwa asupan dan tingkat kecukupan magnesium pada subjek DMT2 lebih tinggi signifikan daripada subjek nondiabetes sedangkan zink dan kromium tidak berbeda signifikan antara kedua kelompok subjek $(\mathrm{p}>0,05)$. Jika dilihat dari kategori tingkat kecukupan maka diperoleh bahwa sebagian besar $(75,0 \%)$ subjek nondiabetes mempunyai asupan magnesium yang defisit ( $<77 \%$ kecukupan magnesium) sedangkan sebagian besar subjek DMT2 (63,0\%) memiliki tingkat kecukupan magnesium yang cukup. Demikian juga berdasarkan analisis asupan zink diketahui bahwa hampir semua subjek nondiabetes mempunyai asupan zink defisit (kurang) dibandingkan dengan kelompok DMT2. Secara umum, semua subjek baik nondiabetes maupun DMT2 mempunyai tingkat kecukupan kromium defisit ( $<77 \%$ kecukupan kromium).

\section{Kontribusi bahan pangan dalam total asupan mikromineral}

Asupan magnesium, zink, dan kromium didukung oleh berbagai sumber bahan pangan seperti ditunjukkan
Tabel 2. Asupan dan tingkat kecukupan $\mathrm{Mg}^{1}, \mathrm{Zn}^{2}$, dan kromium kelompok DMT2 dan nondiabetes ${ }^{3}$

\begin{tabular}{lccc}
\hline $\begin{array}{c}\text { Asupan zat gizi } \\
\text { (per hari) }\end{array}$ & $\begin{array}{c}\text { Kelompok } \\
\text { nondiabetes } \\
\text { (n= 16) }\end{array}$ & $\begin{array}{c}\text { Kelompok } \\
\text { DMT2 } \\
\text { (n=27) }\end{array}$ & $\mathbf{p}^{4}$ \\
\hline Asupan & & & \\
Mg (mg) & $211,0 \pm 33,5$ & $316,1 \pm 22,4$ & $0,010^{*}$ \\
Zn (mg) & $6,2 \pm 0,8$ & $8,4 \pm 0,7$ & 0,051 \\
Kromium ( $\mu$ g) & $8,7 \pm 0,9$ & $10,8 \pm 1,3$ & 0,268 \\
Tingkat kecukupan & & & \\
Mg (\%) & $64,1 \pm 10,6$ & $95,5 \pm 6,9$ & $0,013 *$ \\
Zn (\%) & $55,4 \pm 7,9$ & $76,1 \pm 6,7$ & 0,058 \\
Kromium (\%) & $36,4 \pm 4,2$ & $47,4 \pm 6,9$ & 0,258 \\
\hline
\end{tabular}

${ }^{1} \mathrm{Mg}=$ magnesium; ${ }^{2} \mathrm{Zn}=$ zink; ${ }^{3}$ Data disajikan dalam bentuk rerata (mean) \pm SEM; SEM: standard error means; ${ }^{4}$-two independent test; *Berbeda signifikan $(\mathrm{p}<0,05)$

pada Tabel 3. Ditemukan lima jenis bahan pangan yang memberikan kontribusi paling besar pada asupan magnesium subjek nondiabetes dan DMT2, yaitu sumber karbohidrat, bahan pangan sumber protein nabati, protein hewani, buah-buahan, dan sayur. Berdasarkan uji statistik diketahui bahwa dari kelima jenis bahan pangan tersebut, protein hewani dan buah yang berbeda signifikan antara kelompok nondiabetes dengan DMT2 sebagai sumber magnesium. Sumber magnesium dari bahan pangan minyak dan kelompok pangan lainnya seperti teh, kopi, gula pasir, dan makanan jadi tidak berbeda antar kedua kelompok subjek.

Kontribusi paling besar untuk total asupan zink pada subjek nondiabetes dan DMT2 diperoleh dari jenis pangan sumber karbohidrat, protein hewani, dan protein nabati, tetapi secara statistik tidak berbeda signifikan antara kelompok nondiabetes dengan DMT2. Sumber zink dari jenis pangan sayur-sayuran juga tidak berbeda, kecuali jenis buah-buahan yang menunjukkan perbedaan signifikan antara kelompok nondiabetes dengan DMT2.

Tabel 3 juga menunjukkan bahwa kontribusi bahan pangan untuk asupan kromium pada subjek nondiabetes dan DMT2 paling besar diperoleh dari jenis pangan karbohidrat, protein hewani, protein nabati, dan buah-buahan. Kontribusi jenis pangan protein hewani signifikan lebih tinggi pada subjek nondiabetes daripada subjek DMT2 sedangkan dua jenis pangan lainnya yaitu sayur dan minyak serta kelompok lainnya tidak berbeda pada kedua kelompok subjek. Kontribusi jenis kelompok 
Ni Ketut Sutiari, dkk: Kromium serum dan asupan mikromineral pada penyandang diabetes tipe 2

Tabel 3. Kontribusi dari beberapa sumber bahan pangan (\%) untuk total asupan $\mathrm{Mg}^{1}, \mathrm{Zn}^{2}$, dan kromium pada kelompok DMT2 dan nondiabetes

\begin{tabular}{|c|c|c|c|c|c|}
\hline \multirow{2}{*}{$\begin{array}{c}\text { Sumber bahan } \\
\text { pangan }\end{array}$} & \multicolumn{2}{|c|}{ Nondiabetes } & \multicolumn{2}{|c|}{ DMT2 } & \multirow{2}{*}{$\mathbf{p}^{5}$} \\
\hline & Rerata $^{3} /$ median $^{4}$ & SD $^{3} /$ range $^{4}$ & Rerata $^{3} /$ median $^{4}$ & SD $^{3} /$ range $^{4}$ & \\
\hline \multicolumn{6}{|l|}{ Mg } \\
\hline Karbohidrat $^{3}$ & 19,9 & 8,7 & 22,7 & 9,1 & 0,336 \\
\hline Protein hewani ${ }^{3}$ & 17,7 & 11,3 & 12,2 & 6,5 & $0,049 *$ \\
\hline Protein nabati ${ }^{3}$ & 31,2 & 10,3 & 35,1 & 17,7 & 0,366 \\
\hline Sayuran ${ }^{4}$ & 9,2 & $1,0-24,0$ & 8,9 & $1,0-73,0$ & 0,841 \\
\hline Buah-buahan ${ }^{3}$ & 15,0 & 8,6 & 9,5 & 6,1 & $0,018 *$ \\
\hline Minyak dan lainnya ${ }^{4}$ & 3,8 & $0-21,0$ & 7,4 & $0-31,0$ & 0,481 \\
\hline \multicolumn{6}{|l|}{ Zn } \\
\hline Karbohidrat $^{3}$ & 25,6 & 19,3 & 25,8 & 14,9 & 0,974 \\
\hline Protein hewani ${ }^{3}$ & 31,9 & 14,3 & 33,2 & 26,0 & 0,855 \\
\hline Protein nabati ${ }^{3}$ & 22,0 & 8,7 & 26,0 & 16,6 & 0,303 \\
\hline Sayuran $^{4}$ & 4,3 & $0-29,0$ & 5,4 & $0-70,0$ & 0,791 \\
\hline Buah-buahan ${ }^{4}$ & 8,1 & $0-33,0$ & 3,7 & $0-14,0$ & $0,030 *$ \\
\hline Minyak dan lainnya ${ }^{4}$ & 0,0 & $0-12,0$ & 0,0 & $0-18,0$ & 0,772 \\
\hline \multicolumn{6}{|l|}{ Kromium (Cr) } \\
\hline Karbohidrat $^{4}$ & 36,1 & $21,0-95,0$ & 44,6 & $4,0-59,0$ & 0,209 \\
\hline Protein hewani ${ }^{3}$ & 21,0 & 12,5 & 11,3 & 5,6 & $0,009 *$ \\
\hline Protein nabati ${ }^{4}$ & 15,2 & $2,0-45,0$ & 13,6 & $1,0-50,0$ & 0,940 \\
\hline Sayuran ${ }^{4}$ & 4,2 & $0-23,0$ & 3,9 & $0-57,0$ & 0,555 \\
\hline Buah-buahan ${ }^{4}$ & 10,6 & $0-37,0$ & 7,97 & $0-37,0$ & 0,598 \\
\hline Minyak dan lainnya ${ }^{4}$ & 2,7 & $0-8,0$ & 22,3 & $0-59,0$ & 0,900 \\
\hline
\end{tabular}

${ }^{1} \mathrm{Mg}=$ magnesium; ${ }^{2} \mathrm{Zn}=$ zink; ${ }^{3} \operatorname{Rerata}($ mean $) \pm \mathrm{SD} ; \mathrm{SD}=\operatorname{standar}$ deviasi; ${ }^{4}$ Median $($ range $) ;{ }^{5}$-two independent test $;$ Mann Whitney test; *Berbeda signifikan $(\mathrm{p}<0,05)$; berbeda sangat signifikan $(\mathrm{p}<0,01)$

lainnya untuk asupan kromium pada subjek DMT2 cukup besar (>20\%) dan lebih tinggi dibandingkan dengan subjek nondiabetes.

\section{BAHASAN}

Penelitian menunjukkan bahwa rata-rata kelompok subjek DMT2 berusia lansia ( $>60$ tahun) dan memiliki status obesitas sentral. Diabetes mellitus tipe 2 (DMT2) merupakan penyakit yang berhubungan dengan faktor usia lansia dan obesitas (14). Umur merupakan salah satu faktor risiko penyakit DMT2. Tingginya insiden DMT2 dan prevalensi DMT2 di populasi terlihat meningkat pada usia dewasa awal dan insiden serta prevalensi meningkat pada kelompok dewasa tua (15). Seperti diketahui bahwa kelebihan berat badan (overweight) dan obesitas menjadi penanda kuat yang mendorong terjadinya diabetes dan jumlah kasus diabetes diprediksikan meningkat seiring dengan meningkatnya kasus obesitas baik di negara berkembang atau pun negara sedang berkembang (16).
Negara di Asia memiliki kasus overweight dan obesitas lebih rendah daripada negara Barat jika masih didasarkan pada nilai IMT. Terlepas dari IMT yang lebih rendah, ternyata beberapa negara Asia memiliki prevalensi diabetes sama dan bahkan lebih tinggi dari negara Barat $(17,18)$. Hal ini menggambarkan bahwa risiko DMT2 di Asia dimulai pada nilai IMT yang lebih rendah dibandingkan dengan negara Eropa.

Berdasarkan hasil penelitian, diketahui bahwa kadar GDP subjek DMT2 lebih tinggi dibandingkan dengan subjek nondiabetes (133,9 961,8 vs 100,3 $\pm 16,0)$. American Diabetes Association (ADA) menyebutkan bahwa mereka yang menderita diabetes digolongkan memiliki kontrol glikemik buruk apabila kadar GDP lebih dari atau sama dengan $130 \mathrm{mg} / \mathrm{dl}$ dan kadar hemoglobin terglikasinya (HbA1c) lebih dari 7,0\% (19). Berdasarkan penjelasan ini dapat disimpulkan bahwa subjek DMT2 dalam penelitian mempunyai kontrol glikemik yang buruk. Kontrol glikemik yang buruk dapat menjadi indikasi adanya hiperglikemia kronis pada pasien DMT2 
dan berhubungan dengan timbulnya disfungsi dan kerusakan berbagai organ terutama mata, ginjal, saraf, jantung, dan pembuluh darah (20).

Pemeriksaan biokimia darah juga menunjukkan bahwa kadar kromium serum subjek DMT2 lebih rendah hampir 50\% dibandingkan dengan subjek nondiabetes. Penelitian cross-sectional sebelumnya menemukan bahwa pasien DMT2 dewasa Pakistani mempunyai kadar kromium rendah dan ekskresi kromium urin tinggi (21). Studi review menyimpulkan bahwa metabolisme kromium berubah pada pasien diabetes, yang mana rendahnya kadar kromium pada rambut atau pun darah merupakan refleksi dari penurunan penyerapan kromium pada penyandang DMT2 (22).

Berdasarkan hasil penelitian didapatkan bahwa rerata asupan magnesium seluruh subjek berkisar 200$350 \mathrm{mg} /$ hari dan asupan magnesium pada kelompok DMT2 lebih tinggi signifikan dibandingkan dengan nondiabetes. Jika kebiasaan asupan magnesium subjek nondiabetes yang rendah dan berlangsung kronis maka dapat berisiko mengalami kekurangan magnesium. Beberapa penelitian menyebutkan bahwa kekurangan magnesium berhubungan dengan diabetes mellitus (DM) dan sindrom metabolik (23-26), meskipun mekanisme kerja magnesium sampai saat ini masih digali. Asupan magnesium subjek DMT2 pada penelitian ini lebih tinggi dibandingkan dengan hasil penelitian sebelumnya tentang asupan magnesium pada pasien rawat jalan DMT2 yang melaporkan bahwa asupan magnesium pasien rawat jalan DMT2 di RSUD Al-Ihsan Provinsi Jawa Barat berkisar antara 162 - $317 \mathrm{mg}$ dengan rerata $270 \mathrm{mg}$ /hari (10).

Seperti halnya mineral lain, magnesium diserap dalam tubuh berbanding terbalik dengan jumlah yang konsumsi. Tingkat fraksi penyerapan magnesium dalam tubuh manusia antara 30\% dan 50\% apabila rata-rata asupan magnesium 300-500 mg/hari (27). Dari penjelasan tingkat penyerapan tersebut diketahui bahwa kemungkinan asupan magnesium pada kelompok subjek DMT2 dapat diserap sekitar 30-50\% sedangkan magnesium nondiabetes diserap kurang dari $30 \%$. Penyerapan magnesium yang berkurang dapat dipengaruhi oleh fitat, oksalat dari buahbuahan, sayuran, biji-bijian, konsumsi alkohol berlebihan, dan konsumsi obat diuretik. Selain itu, ada faktor fosfor, kalsium, dan protein yang dapat menurunkan penyerapan magnesium (26). Dilihat dari faktor fitat diperoleh bahwa asupan serat subjek nondiabetes berkisar antara 1,3-481,0 $\mathrm{g} /$ hari dengan median 5,8 $\mathrm{g}$ /hari sedangkan asupan serat pangan subjek DMT2 sebesar 4,6-25,0 g/hari dengan rerata $11,9 \mathrm{~g} /$ hari. Hasil tersebut menunjukkan asupan serat semua subjek masih kurang dari AKG serat (22$33 \mathrm{~g} /$ hari) sehingga kemungkinan serat pangan tidak akan menurunkan penyerapan magnesium. Meskipun demikian, yang perlu mendapatkan perhatian yaitu subjek nondiabetes yang memiliki asupan serat melebihi AKG dan bahkan sampai lebih dari $100 \mathrm{~g} /$ hari, sebaiknya membatasi asupan serat pangan yang berlebih dengan membatasi konsumsi sumber serat (biji-bijian atau pun buah-buahan). Seperti diketahui bahwa kedua jenis pangan tersebut pada penelitian ini memberikan kontribusi cukup besar dalam asupan magnesium subjek nondiabetes. Fitat yang terkandung dalam makanan tinggi serat menyebabkan magnesium terikat pada gugus fosfat dari phytates, yang menyebabkan penurunan penyerapan magnesium. Selain itu, asupan protein rendah $(<30 \mathrm{~g}$ /hari) dan tinggi ( $>94 \mathrm{~g} /$ hari) dapat berefek dalam mengurangi penyerapan magnesium (24). Berdasarkan hasil recall diperoleh bahwa kedua kelompok subjek mempunyai rerata asupan protein sebesar 63-74 g/hari, untuk itu dapat disimpulkan bahwa jumlah asupan protein subjek tidak akan mengganggu absorpsi magnesium.

Lebih lanjut, zink merupakan salah satu jenis mineral mikro yang dikaitkan dengan kejadian diabetes dan prediabetes. Seperti yang dilaporkan dalam penelitian sebelumnya bahwa mengkonsumsi tinggi zink mungkin berkaitan dengan rendahnya risiko munculnya DMT2 pada kelompok wanita, akan tetapi hasil tersebut memerlukan konfrimasi studi-studi yang lain dan eksplorasi mekanisme potensi kerja zink pada DMT2 (8). Berdasarkan hasil penelitian ini ditemukan bahwa tidak ada perbedaan asupan zink antara kedua kelompok, meskipun nilai asupan zink DMT2 lebih tinggi daripada nondiabetes. Penemuan ini sejalan dengan penelitian sebelumnya $(28,29)$ yang membuktikan bahwa asupan zink antara diabetes dengan nondiabetes (masyarakat sehat) tidak berbeda. Namun, asupan zink subjek DMT2 pada penelitian ini lebih tinggi dibandingkan dengan asupan zink DMT2 dalam beberapa penelitian lain yaitu sebesar $8,4 \pm 0,7 \mathrm{mg} /$ hari vs $4,52-6,47 \mathrm{mg} /$ hari (28) dan 
$8,4 \pm 0,7 \mathrm{mg} /$ hari vs $6,3 \pm 0,7 \mathrm{mg} /$ hari (29). Total asupan zink akan sangat terpengaruh oleh adanya pemilihan jenis bahan pangan yang dikonsumsi (30). Disebutkan pula bahwa asupan zink berkorelasi dengan asupan protein, tergantung dari sumber proteinnya. Berdasarkan hasil analisis persentase kontribusi pangan terhadap asupan zink, diperoleh bahwa jenis bahan pangan sumber protein hewani memberikan kontribusi paling besar pada kedua kelompok subjek.

Beberapa subjek DMT2 mempunyai tingkat konsumsi zink yang tergolong defisit, bahkan hampir semua subjek nondiabetes $(87,5 \%)$ dalam studi ini juga tingkat konsumsinya defisit. Tingkat konsumsi subjek sangat dipengaruhi oleh jumlah asupan zink dan jenis bahan pangan yang dikonumsi. Seperti halnya dengan mineral lain, sistem metabolisme zink dikenal sebagai regulasi homeostatis, yang dipahami sebagai keseimbangan antara penyerapan zink dari makanan (endogen) dan ekskresi zink. Homeostatis zink tetap terjaga ketika penyerapan zink melebihi jumlah zink yang dapat dimanfaatkan tubuh, maka kelebihan zink akan dieksresikan melalui urin (30). Penyerapan zink di dalam tubuh manusia dipengaruhi oleh faktor fitat yang terkandung pada beberapa jenis pangan (kacangkacangan, sayuran atau buah) dan faktor makanan hasil fermentasi. Pemilihan varian bahan pangan yang rendah fitat seperti barley, jagung atau beras mungkin dapat meningkatkan bioavailabilitas zink dari pangan tersebut (31). Roti, sebagai salah satu makanan hasil fermentasi ternyata mampu mengurangi kadar asam fitat dan signifikan meningkatkan penyerapan zink (30). Hasil analisis recall dan SQ-FFQ menunjukkan bahwa semua jenis bahan pangan memberikan kontribusi asupan zink subjek. Bioavailabilitas zink ditentukan dari jumlah zink yang tersedia dari matriks makanan dan jumlah total zink dalam makanan $(32,33)$. Sebagai tambahan dalam pembahasan asupan zink yaitu diet rendah zink akan meningkatkan penyerapan fraksi zink tetapi menurunkan penyerapan total zink dan akan terbalik kejadiannya apabila diet yang cukup zink (34).

Sekitar tahun 1950, kromium sudah dibahas para peneliti dan disebutkan dapat memberikan manfaat bagi kesehatan diabetisi yaitu kromium mungkin mampu memperbaiki kontrol glikemik dan meningkatkan sensitivitas insulin. Namun, sampai saat ini manfaat tersebut belum konklusif dan mekanisme kerja kromium masih terus digali peneliti. Penelitian dilakukan untuk menilai status kromium subjek yang didasarkan pada nilai asupan kromium. Hasil penelitian menunjukkan bahwa asupan kromium subjek DMT2 sedikit lebih tinggi daripada subjek nondiabetes, tetapi secara statistik tidak berbeda signifikan dan semua subjek dalam penelitian belum memenuhi kecukupan kromium sesuai dengan AKG yang dianjurkan (tingkat kecukupannya $<77 \%$ ). Nilai kromium dalam AKG Indonesia pada kelompok umur di atas 50 tahun berkisar antara 20-30 $\mu \mathrm{g} /$ hari. Rerata asupan kromium pada seluruh subjek penelitian ini sebesar 8,7-10,8 $\mu$ g/hari tidak berbeda dengan hasil penelitan sebelumnya yaitu 9,3-10,2 $\mu \mathrm{g} /$ hari (29). Belum adanya data nilai kromium dalam daftar komposisi bahan pangan (DKBM) di Indonesia sehingga analisis kromium tergantung pada DKBM dari Jepang dan jenis pangan yang dikonsumsi subjek terlebih dahulu disesuaikan dengan kemiripan variasi jenis pangan yang tersedia dalam daftar. Keterbatasan dalam hal nilai kandungan kromium pada beberapa jenis pangan yang dikonsumsi oleh subjek penelitian adalah keterbatasan dalam penelitian ini. Oleh karena itu, perlu dilakukan survei analisis kandungan kromium berbagai jenis pangan dan makanan jadi di Indonesia.

Bahan makanan sumber kromium dapat ditemukan pada biji-bijian, kacang-kacangan, beberapa sayuran (misalnya brokoli dan jamur), hati, daging olahan, dan sereal siap makan $(35,36)$. Sumber kromium yang lain adalah telur, kacang kering, produk gandum, dan cokelat hitam (35). Kromium terkandung pada berbagai jenis pangan, tetapi informasi nilai kandungan kromium dalam pangan masih kurang lengkap. Hasil penelitian menunjukkan bahwa tidak ada perbedaan persentase kontribusi pada semua jenis pangan kecuali jenis pangan protein hewani. Jenis pangan hewani seperti daging ayam mampu memberikan sedikit kontribusi untuk jumlah asupan kromium bagi subjek nondiabetes sedangkan produk makanan khusus diabetes (masuk dalam kelompok pangan lainnya) ikut memberikan kontribusi besar dalam jumlah asupan kromium subjek DMT2. Pada penelitian ini, produk makanan khusus bagi penyandang diabetes yang dikonsumsi subjek DMT2 seperti produk susu dan gula khusus diabet yang mengandung kromium. 
Nilai asupan magnesium, zink, dan kromium, serta kadar kromium serum telah diukur dan dianalisis dalam penelitian ini. Namun, penelitian ini memiliki keterbatasan dalam penilaian kadar ekskresi magnesium, zink, dan kromium dalam urin, pemeriksaan kadar magnesium dan zink dalam serum, serta nilai kandungan kromium beberapa jenis bahan pangan atau makanan di Indonesia yang dikonsumsi subjek.

\section{SIMPULAN DAN SARAN}

Kromium serum DMT2 lebih rendah dibandingkan dengan nondiabetes. Jenis mineral magnesium, zink, dan kromium merupakan jenis mineral yang terkait dengan perbaikan kontrol glikemik dan resistensi insulin. Penyandang DMT2 mempunyai asupan magnesium yang lebih tinggi dibandingkan dengan asupan magnesium nondiabetes dan telah memenuhi kecukupan magnesium yang dianjurkan. Asupan zink dan kromium antara penyandang DMT2 dan nondiabetes tidak berbeda, meskipun sebagian besar penyandang DMT2 (87,5\%) mempunyai asupan zink yang cukup. Asupan kromium pada penyandang DMT2 dan nondiabetes tergolong kurang dari nilai kecukupan kromium yang dianjurkan.

Saran untuk penelitian lebih lanjut sebaiknya melakukan pengukuran mineral magnesium, zink, dan kromium pada urin dan serum untuk memberikan gambaran status mineral magnesium, zink, dan kromium pada penyandang DMT2 dan mungkin dapat menggambarkan nilai bioavailabilitas mineral serta melakukan studi eksplorasi pada mikronutrien lain (vitamin). Saran kepada pemangku kebijakan yaitu sebaiknya melakukan kajian kandungan kromium setiap bahan makanan atau makanan khas daerah di Indonesia guna memperkaya kandungan gizi dalam Daftar Komposisi Bahan Pangan di Indonesia.

\section{RUJUKAN}

1. American Diabetes Association. Standards of medical care in diabetes. Diabetes Care 2015;39(1):s1-s119.

2. Perkumpulan Endokrinologi Indonesia. Konsensus pengelolaan dan pencegahan diabetes melitus tipe 2 di Indonesia. Jakarta: Perkumpulan Endokrinologi Indonesia; 2011.
3. Nsonwu AC, Usoro CAO, Etukudo MH, Usoro IN. Serum and urine levels of chromium and magnesium in type 2 diabetics in Calabar, Nigeria. Mal J Nutr 2005;11(2):13342.

4. Praveeena S, Sujatha P, Sameera K. Trace elements in diabetes mellitus. J Clin Diagn Res 2013;7(9):1863-5.

5. Nsonwu AC, Usoro CAO, Etukudo MH, Usoro IN. Glycemic control and serum and urine levels of zinc and magnesium in diabetics in Calabar, Nigeria. Pak J Nutr 2006;5(1):75-8.

6. Kobayashi Y, HattoriM, Wada S, Iwase H, Kadono M, Tatsumi H, et al. Assessment of daily food and nutrient intake in Japanese type 2 diabetes mellitus patients using dietary reference intakes. Nutrients 2013;5:2276-88.

7. Walti MK, Zimmermann MB, Spinas GA, Jacob S, Hurrel RF. Dietary magnesium intake in type 2 diabetes. Eur J Clin Nutr 2002;56:409-14.

8. Sun Q, Van Dam RM, Willett WC, Hu FB. Prospective study of zinc intake and risk of type 2 diabetes in women. Diabetes Care 2009;32(4):629-34.

9. Vashum KP, McEvoy M, Shi Z, Milton AH, Islam MD, Sibbritt D, et al. Is dietary zinc protective for type 2 diabetes? Results from the Australian longitudinal study on women's health. BMC Endocrine Disorders 2013;13(40):1-8.

10. Faradhita A, Handayani D, Kusumastuty I. Hubungan asupan magnesium dan kadar glukosa dadrah puasa pasien rawat jalan diabetes mellitus tipe 2. Indonesian Journal of Human Nutrition 2014;1(2):71-88.

11. Cochran WG. Sampling technique. New York: John Willey and Son; 1982.

12. Ghosh D, Bhattacharya B, Mukherjee B, Manna B, Sinha M, Chowdhury S, et al. Role of chromium supplementation in Indians with type 2 diabetes mellitus. J of Nut Biochem 2002;13:690-697.

13. Gibson RS. Principles of nutritional assessment. New York: Oxford University Press; 2005.

14. Ajibola RS, Ogundahunsi OA, Soyinka OO, Ogunyemi EO, Odewabi AO. Serum chromium, molybdenum, zinc and magnesium levels in diabetes mellitus patients in Sagamu, South West Nigeria. Asian Journal of Medical Sciences 2014;6(2):15-9.

15. Chen L, Magliano DJ, Zimmet PZ. The worldwide epidemiology of type 2 diabetes mellitus - present and future perspectives. Nat Rev Endocrino 2012;8:228-36.

16. Hu FB. Globalization of diabetes the role of diet, lifestyle and genes. Diabetes Care 2011;34:1249-57.

17. Huxley R, James WP, Barzi F, Patel JV, Lear SA, Suriyawongpaisal $\mathrm{P}$, et al. Ethnic comparisons of the crosssectional relationships between measures of body size with diabetes and hypertension. Obes Rev 2008;9(1):53-61. 
18. Chan JC, Malik V, Jia W, Kadowaki T, Yajnik CS, Hu FB, et al. Diabetes in Asia: epidemiology, risk factors, and pathophysiology. JAMA 2009;301(20):2129-40.

19. American Diabetes Association. Diagnosis and classification of diabetes mellitus. Diabetes Care 2011;1:S62-S69.

20. Centers for Disease Control and Prevention. National diabetes fact sheet 2011. [series online] 2011 [cited 2016 Jan 20]. Available from: URL: https://www.cdc.gov/ diabetes/pubs/pdf/ndfs_2011.pdf.

21. KaziT, Afridi H, Kazi N, Jamali M, Arain M, Jalbani N, et al. Copper, chromium, manganese, iron, nickel, and zinc levels in biological samples of diabetes mellitus patients. Biol Trace Elem Res 2008;122(1):1-18.

22. Kaur B, Henry J. Micronutrient status in type 2 diabetes: a review. Adv Food Nutr Res 2014;71:55-100.

23. Guerrero-Romero F, Rodríguez-Morán M. Hypomagnesemia, oxidative stress, inflammation, and metabolic syndrome. Diabetes Metab Res Rev 2006;22:471-6.

24. Guerrera MP, Mao JJ, Volpe SL. Therapeutic uses of magnesium. Am Family Phys 2009;80:157-62.

25. Davì G, Santilli F, Patrono C. Nutraceuticals in diabetes and metabolic syndrome. Cardiovasc Therapeut 2010;28:21626.

26. Volpe SL. Magnesium, the metabolic syndrome, insulin resistance and type 2 diabetes mellitus. Crit Rev Food Sci Nutr 2008;48:293-300.

27. Volpe SL. Magnesium. In: Erdman JWJ, Macdonald IA, Zeisel SH, editors. Present knowledge in mutrition tenth edition. Iowa USA: Wiley Blackwell (John Wiley \& Sons); 2012.

28. Winokan MAC, Sayogo S, Tarigan THE. Serum zinc level in type 2 diabetes and its association with zinc, animal protein, phytate and dietary fiber intakes. Maj Kedokt Indon 2010;60(2):60-6.

29. Unjiati, Wirjatmadi B, Adriani M. Chromium and zinc level of ptients with type 2 diabetes and non-diabetes. Biochem Physiol 2015;S5(10):1-5.

30. Holt RR, Uriu-Adams JY, Keen CL. Zinc. In: Erdman JWJ, Macdonald IA, Zeisel SH, editors. Present knowledge in mutrition tenth edition. Iowa USA: Wiley Blackwell (John Wiley \& Sons); 2012.

31. Lonnerdal B, Mendoza C, Brown KH, Rutger JN, Raboy $\mathrm{V}$. Zinc absorption from low phytic acid genotypes of maize (Zea mays L), barley (Hordeum vulgare $\mathrm{L}$ ), and rice (Oryza sativa $\mathrm{L}$ ) assessed in a suckling rat pup model. J Agric Food Chem 2011;59:4755-62.

32. Hambidge KM, Miller LV, Westcott JE, Seng X, Krebs NF. Zinc bioavailability and homeostasis. Am J Clin Nutr 2010;91(5):1478S-83S.

33. King JC. Does zinc absorption reflect zinc status? Int $\mathrm{J}$ Vitam Nutr Res 2010;80:300-6.

34. Chung CS, Stookey J, Dare D, Welch R, Nguyen TQ, Roehl R, et al. Current dietary zinc intake has a greater effect on fractional zinc absorption than does longer term zinc consumption in healthy adult men. Am J Clin Nutr 2008;87(5):1224-9.

35. Byrd-Bredbenner C, Beshgetoor D, Moe G, Berning J. Wardlaw's prespectives in nutrition eighth edition. New York: McGraw-Hill; 2009.

36. Nielsen FH. Manganese, molybdenum, boron, chromium, and other trace elements. In: Erdman JWJ, Macdonald IA, Zeisel SH, editors. Present knowledge in mutrition tenth edition. Iowa USA: Wiley Blackwell (John Wiley \& Sons); 2012. 


\section{Erratum}

Renyoet BS, Martianto D, Iskandar D. Potensi kerugian ekonomi akibat biaya rawat inap dan rawat jalan pada balita yang mengalami obesitas sampai dewasa di Indonesia. Jurnal Gizi Klinik Indonesia 2016;13(2):43-50.

Perbaikan judul dikoreksi oleh penulis menjadi: Potensi kerugian ekonomi akibat biaya rawat inap dan rawat jalan pada balita obesitas yang diprediksi mengalami obesitas saat dewasa di Indonesia.

Terjadi kesalahan pada nama penulis ketiga, yang sebelumnya dilaporkan Dadang Iskandar dikoreksi menjadi Dadang Sukandar.

Kesalahan juga muncul pada ucapan terima kasih yang seharusnya ditambahkan kalimat ucapan terima kasih kepada Badan Penelitian dan Pengembangan Kesehatan, Badan Pusat Statistik, dan Kementerian Kesehatan RI yang telah membantu dalam penyediaan data penelitian.

doi: $10.22146 /$ ijen.22899

\section{Erratum}

Yee LP, Wah CS. Application of red pitaya powder as a natural food colourant in fruit pastille. Jurnal Gizi Klinik Indonesia 2017;13(3):111-120.

The author name was corrected to: Low Pinn Yee, Tan Chin Ping, Lim Pek Kui, Chan Sook Wah.

The corresponding author was corrected to: Chan Sook Wah, School of Biosciences, Taylor's University No 1, Jalan Taylor's 47500 Subang Jaya, Selangor, Malaysia, e-mail: sookwah.chan@taylors.edu.my

doi: $10.22146 /$ ijen. 17863

\section{Erratum}

Sutiari NK, Rimbawan, Kusharto CM, Ascobat P, Effendi AT. Kromium serum dan asupan mikromineral pada penyandang diabetes tipe 2. Jurnal Gizi Klinik Indonesia 2017;13(4):135-143.

Kalimat simpulan pada bagian abstract dikoreksi oleh penulis menjadi: Conclusion: The study showed that serum chromium in DMT2 patients is lower than nondiabetic. The magnesium intake among DMT2 is higher as compare to nondiabetic, while zinc and chromium intake are not different in both group dan abstrak dikoreksi menjadi: Simpulan: Kromium serum pada DMT2 lebih rendah daripada nilai kromium serum nondiabetes. Asupan magnesium pada penyandang DMT2 lebih tinggi dibandingkan dengan nondiabetes, sedangkan asupan zink dan kromium pada kedua kelompok tidak berbeda.

Kalimat pada simpulan dan saran dikoreksi menjadi:

Kromium serum DMT2 lebih rendah dibandingkan dengan nondiabetes. Jenis mineral magnesium, zink, dan kromium merupakan jenis mineral yang terkait dengan perbaikan kontrol glikemik dan resistensi insulin. Penyandang DMT2 mempunyai asupan magnesium yang lebih tinggi dibandingkan dengan asupan magnesium nondiabetes dan telah memenuhi kecukupan magnesium yang dianjurkan. Asupan zink dan kromium antara penyandang DMT2 dan nondiabetes tidak berbeda, meskipun sebagian besar penyandang DMT2 (87,5\%) mempunyai asupan zink yang cukup. Asupan kromium pada penyandang DMT2 dan nondiabetes tergolong kurang dari nilai kecukupan kromium yang dianjurkan.

Saran untuk penelitian lebih lanjut sebaiknya melakukan pengukuran mineral magnesium, zink, dan kromium pada urin dan serum untuk memberikan gambaran status mineral magnesium, zink, dan kromium pada penyandang DMT2 dan mungkin dapat menggambarkan nilai bioavailabilitas mineral serta melakukan studi eksplorasi pada mikronutrien lain (vitamin).

doi: $10.22146 / \mathrm{ijen} .18883$ 


\title{
Kromium serum dan asupan mikromineral pada penyandang diabetes tipe 2
}

\author{
Chromium serum and dietary micromineral intake among type II diabetic patients
}

\author{
Ni Ketut Sutiari ${ }^{1}$, Rimbawan ${ }^{2}$, Clara M Kusharto ${ }^{2}$, Purwantyastuti ${ }^{3}$, Adi T Effendi ${ }^{4}$
}

${ }^{1}$ Program Studi Ilmu Gizi Manusia, Sekolah Pascasarjana Institut Pertanian Bogor

${ }^{2}$ Departemen Gizi Masyarakat, Fakultas Ekologi Manusia Institut Pertanian Bogor

${ }^{3}$ Departemen Farmakologi, Fakultas Kedokteran Universitas Indonesia

${ }^{4}$ Rumah Sakit Pertamedika Sentul City Bogor

\begin{abstract}
Background: Status of minerals such as zinc, magnesium and chromium among diabetic patients are considered lower than nondiabetic peoples, both in the serum and intake. Some reviews shows that those minerals contribute to carbohydrate metabolism among diabetic patients. Objective: This study aims to explore intake of zinc, magnesium and chromium among DMT2 in Denpasar. Method: This is a cross-sectional analytic study. Population were all (70) DMT2 patients registered at Chronic Disease Service (Prolanis) at two Primary Health Care (PHC) Denpasar Utara III PHC and Denpasar Timur I PHC. Sample for the study was DMT2 patients and non-diabetic people age 50-70 years reside in Denpasar city. DMT2 patients were randomly selected with simple random technique, while non-diabetic peoples were non-randomly selected. Level of serum chromium was measured by AAS method, whereas microminerals intake were collected by recall and SQ-FFQ method. Data was analyzed descriptively and differences were tested with two independent t-test at $95 \%$ confidence level. Results: The mean of serum chromium DMT2 and non-diabetic were $0.044 \mathrm{mg} / \mathrm{L}$ and $0.094 \mathrm{mg} / \mathrm{L}$ respectively. The mean $\pm S E M$ magnesium (DMT2 316.1 $\pm 22.4 \mathrm{mg} /$ day; non-diabetic $211.0 \pm 33.5 \mathrm{mg} /$ day), zinc intake was (DMT2 $8.4 \pm 0.7 \mathrm{mg} /$ day; non-diabetic $6.2 \pm 0.8 \mathrm{mg} /$ day), and chromium (DMT2 $10.8 \pm 1.3 \mu \mathrm{g} /$ day; non-diabetic $8.7 \pm 0.9 \mu \mathrm{g} /$ day). Significant difference was found on magnesium intake ( $p=0.01)$. Conclusion: The study showed that zinc, magnesium and chromium intake is appear higher among DMT2 patients compare to non-diabetic in Denpasar region.
\end{abstract}

KEY WORDS: magnesium; non-diabetic; serum chromium; type 2 diabetes; zinc

\begin{abstract}
ABSTRAK
Latar belakang: Status mineral zink, magnesium, dan kromium pada penyandang diabetes diduga sangat rendah dibandingkan dengan nondiabetes, baik dalam serum maupun konsumsi makannya. Beberapa hasil review menyebutkan bahwa jenis mineral tersebut dapat membantu metabolisme karbohidrat pada penyandang diabetes. Tujuan: Menganalisis asupan gizi zink, magnesium, dan kromium penyandang diabetes tipe 2 (DMT2) di Kota Denpasar. Metode: Jenis penelitian ini adalah studi cross sectional analitik. Populasi merupakan seluruh penyandang DMT2 yang terdaftar dalam Program Pelayanan Penyakit Kronis (Prolanis, khusus penyakit diabetes) di Puskesmas III Denpasar Utara dan Puskesmas I Denpasar Timur berjumlah 70 orang. Sampel penelitian adalah penyandang DMT2 dan nondiabetes yang berusia 50-70 tahun, berdomisili di Denpasar. Penarikan subjek DMT2 dengan simple random sampling sedangkan nondiabetes menggunakan nonrandom sampling. Kromium serum diperiksa dengan metode AAS sedangkan asupan mikromineral dikumpulkan dengan metode recall dan SQ-FFQ. Analisis data dilakukan secara deskriptif (univariat) dan uji t-two independent dengan tingkat ketelitian 95\%. Hasil: Rerata kadar kromium serum DMT2 dan nondiabetes masing-masing 0,044 mg/L dan 0,094 mg/L. Rerata \pm SEM asupan magnesium (DMT2 316,1 $\pm 22,4 \mathrm{mg} /$ hari; nondiabetes 211,0 $\pm 33,5$ $\mathrm{mg} /$ hari), zink (DMT2 $8,4 \pm 0,7 \mathrm{mg} /$ hari; nondiabetes $6,2 \pm 0,8 \mathrm{mg} / \mathrm{hari}$ ), dan kromium (DMT2 10,8 $\pm 1,3 \mu \mathrm{g} / \mathrm{hari}$; nondiabetes $8,7 \pm 0,9$ $\mu \mathrm{g} /$ hari) menunjukkan adanya perbedaan signifikan pada asupan magnesium $(\mathrm{p}=0,01)$ antara diabetes dan nondiabetes. Simpulan: Kromium serum pada DMT2 lebih rendah daripada nilai kromium serum nondiabetes. Asupan zink, magnesium, dan kromium kelompok DMT2 lebih tinggi dibandingkan dengan nondiabetes di Kota Denpasar.
\end{abstract}

KATA KUNCI: magnesium; nondiabetes; kromium serum; diabetes tipe 2; zink 


\section{PENDAHULUAN}

Salah satu pilar dalam konsensus pengobatan dan pencegahan diabetes mellitus tipe 2 (DMT2) yaitu memberikan terapi gizi medis (medical nutrition therapy). Terapi gizi bagi DMT2 ditekankan pada jadwal pemberian makan, jenis makanan/bahan makan yang baik bagi DMT2, dan perhatian pada porsi makan serta menjaga keseimbangan zat gizi makro dan mikro $(1,2)$. Peran beberapa trace mineral dalam penelitian klinis sedang berkembang pada beberapa dekade terakhir. Beberapa mineral tersebut akan mempunyai peran esensial dalam beberapa proses metabolik tubuh manusia apabila konsentrasi mineral dalam tubuh normal (3). Penelitian sebelumnya melaporkan bahwa ada potensi aksi insulin pada kasus diabetes dengan keberadaan mikromineral atau trace mineral, seperti kromium, magnesium, vanadium, zink, molibdenum, mangan, dan selenium (4). Kekurangan mikromineral diduga dapat menyebabkan penyakit kronis seperti diabetes atau sebaliknya penyakit kronis yang menyebabkan kekurangan mikromineral tertentu, kedua pernyataan ini masih belum jelas (5).

Hasil penelitian di Jepang menunjukkan bahwa sebagian besar (>50\%) penyandang DMT2 mempunyai asupan magnesium dan zink lebih rendah dari nilai estimated average requirement (EAR) (6). Namun, penelitian di Swiss melaporkan bahwa asupan magnesium antara kelompok diabetes dan kontrol tidak berbeda, bahkan asupan magnesium kedua kelompok tersebut melebihi nilai standar kecukupan gizi magnesium Swiss (7). Manfaat yang lainnya, yaitu kecukupan zink dari makanan ternyata mampu menurunkan risiko DMT2 pada wanita $(8,9)$.

Penelitian mengenai asupan gizi mineral pada penyandang DMT2 di negara-negara lain untuk saat ini masih jarang dan yang terlaporkan merupakan hasil penelitian lebih dari 10 tahun. Di Indonesia, penelitian mengenai status mikromineral dalam makanan dan darah pada penyandang DMT2 juga belum banyak terlaporkan. Dua tahun yang lalu, terdapat studi asupan magnesium yang dihubungkan dengan kadar glukosa darah pasien DMT2 rawat jalan di Rumah Sakit Umum Daerah (RSUD) Al-Ihsan Jawa Barat. Studi ini menemukan bahwa semakin tinggi asupan magnesium maka semakin rendah kadar glukosa darah puasa pasien sehingga pasien DMT2 disarankan untuk memperhatikan kecukupan asupan magnesium mereka (10). Dengan demikian, penelitian ini bertujuan untuk memberikan profil kromium serum serta asupan magnesium, zinc, dan kromium yang dianalisis dari jenis dan porsi makan yang dikonsumsi penyandang DMT2.

\section{BAHAN DAN METODE}

Penelitian ini merupakan studi cross-sectional analitik yang dilaksanakan pada dua Puskesmas di Kota Denpasar, yaitu Puskesmas III Denpasar Utara dan Puskesmas I Denpasar Timur pada bulan Juli - Oktober tahun 2015. Pemilihan lokasi penelitian dilakukan dengan pertimbangan bahwa pada kedua puskesmas tersebut terdapat penyandang DMT2 dan nondiabetes dan akses menuju lokasi terjangkau.

Populasi target adalah penyandang DMT2 yang terdaftar dalam Program Pelayanan Penyakit Kronis (Prolanis, khusus penyakit diabetes), masyarakat pengunjung puskesmas, dan petugas puskesmas yang dinyatakan tidak menyandang diabetes berdasarkan hasil pemeriksaan dokter puskesmas, berusia 50-70 tahun serta berdomisili di Kota Denpasar. Jumlah populasi target penyandang DMT2 sebesar 70 orang sedangkan populasi target nondiabetes sebesar 80 orang. Subjek penelitian merupakan bagian dari populasi yaitu penyandang DMT2 dan nondiabetes. Kriteria inklusi yaitu laki-laki maupun wanita, berusia 50-70 tahun, berdomisili di Kota Denpasar, dan bersedia menjadi subjek penelitian dengan menandatangani informed consent. Kriteria eksklusi adalah penyandang DMT2 yang sedang mengalami komplikasi kronis saat penelitian berdasarkan laporan medis dokter, memiliki pendengaran dan komunikasi yang tidak bagus, dan masyarakat nondiabetes yang sedang sakit berdasarkan hasil pemeriksaan dokter. Informed consent adalah formulir yang terdiri dari naskah penjelas yang mengandung penjelasan mengenai cara pengumpulan data, kemungkinan ada atau tidaknya efek samping saat pengambilan sampel darah, petunjuk yang dapat dihubungi apabila terjadi sesuatu terkait dengan kesehatan subjek, dan lembar persetujuan yang berisi pernyataan bahwa subjek menyetujui sebagai subjek dalam penelitian.

Besar sampel dihitung berdasarkan rumus besar sampel untuk data berskala kontinyu dan alokasi 
proporsional populasi (11). Berdasarkan survei awal terhadap populasi DMT2 dan nondiabetes diketahui proporsi populasi DMT2 (w1) sebesar 0,466 dan proporsi populasi nondiabetes (w2) sebesar 0,50 ; tingkat kepercayaan 95\%; nilai presisi antarkelompok sebesar 0,55 ; dan standar deviasi (SD) glukosa darah puasa (GDP) DMT2 sebesar 2,7 mmol/L dan SD nondiabetes sebesar $0,1 \mathrm{mmol} / \mathrm{L}$ (12). Dari rumus besar sampel didapatkan jumlah sampel minimal sebanyak 43 orang. Subjek penelitian yang telah memenuhi kriteria dipilih secara simple random sampling sedangkan subjek nondiabetes dipilih secara nonrandom sampling.

Variabel yang diteliti yaitu variabel berskala kontinyu yang meliputi variabel status gizi berdasarkan nilai indeks massa tubuh (IMT) dan lingkar pinggang (LP), kadar glukosa darah puasa (GDP), kadar kromium serum, asupan magnesium, asupan zink, dan asupan kromium. Status gizi subjek menurut IMT diperoleh melalui penimbangan berat badan (BB) dan pengukuran tinggi badan (TB). Penimbangan BB menggunakan timbangan digital Camry dengan ketelitian $0,1 \mathrm{~kg}$ sedangkan pengukuran TB menggunakan mikrotoise dengan ketelitian $0,1 \mathrm{~cm}$. Status gizi subjek menurut nilai LP diperoleh melalui pengukuran LP menggunakan pita meter dengan ketelitian $0,1 \mathrm{~cm}$.

Parameter biokimia darah diperiksa dengan memakai sampel darah vena sebanyak $5 \mathrm{cc}$ yang diambil oleh petugas Laboratorium Kesehatan Daerah Provinsi Bali pada pukul 08.00-10.00 WITA. Satu hari sebelum pengambilan darah, subjek diminta berpuasa sekitar 10 jam. Kadar GDP diperiksa dengan metode GOD-PAP enzymatic colorimetric di Laboratorium Kesehatan Daerah Provinsi Bali sedangkan kromium serum diperiksa dengan metode Atomic Absorbance Spectrophotometric (AAS) di Laboratorium Kimia Terpadu Universitas Udayana Denpasar.

Data asupan makanan dikumpulkan dengan metode recall $2 \times 24$ jam secara berturut-turut sedangkan kebiasaan makan subjek satu bulan terakhir dikumpulkan dengan metode Semi Quantitative Food Frequency Questionnaire (SQ-FFQ) yang dilakukan oleh peneliti dan dibantu oleh enumerator yaitu mahasiswa lulusan Jurusan Gizi Poltekes Kemenkes Denpasar. Asupan makan dianalisis dengan software Nutrisurvey 2007 for windows untuk memperoleh nilai kandungan magnesium dan zink masing- masing jenis bahan makanan sehingga diperoleh nilai total asupan magnesium dan zink per hari. Nilai kandungan kromium dari asupan makanan dianalisis secara manual dengan mengacu pada beberapa sumber bahan makanan dalam Daftar Komposisi Bahan Makanan (DKBM) yang dikeluarkan oleh Ministry of Education, Culture, Sports, Science and Technology Jepang dan diperoleh total asupan kromium per hari. Asupan mineral dikategorikan menjadi 2 yaitu cukup apabila tingkat kecukupan mineral $\geq 77 \%$ dan defisit (kurang) apabila tingkat kecukupan mineral $<77 \%$ (13). Tingkat kecukupan mineral dihitung dengan membagi antara asupan mineral dengan kecukupan mineral sesuai dengan Angka Kecukupan Gizi yang Dianjurkan (AKG) Indonesia tahun 2014.

Uji normalitas dilakukan pada data penelitian ini untuk menilai data berdistribusi normal atau tidak. Data disajikan dalam bentuk univariat (rerata, standar deviasi/ $\mathrm{SD}$, standar error mean/SEM, dan persentase). Analisis statistik yang digunakan adalah uji t-two independent samples jika data terdistribusi normal serta uji MannWhitney apabila data tidak berdistribusi normal dengan tujuan untuk menguji kemaknaan perbedaan 2 rerata terhadap 2 kelompok. Protokol penelitian ini termasuk juga informed consent yang dipakai dalam penelitian telah disetuji oleh Komisi Etik Penelitian dan Pengembangan Kesehatan Fakultas Kedokteran Universitas Udayana dan Rumah Sakit Umum Pusat Sanglah (RSUP) Denpasar dengan dikeluarkannya surat keterangan lolos kaji etik (ethical clearance) dengan Nomor: 1439/UN.14.2/ Litbang/2015 tanggal 30 Juli 2015.

\section{HASIL}

\section{Status gizi dan profil biokimia darah subjek penelitian}

Selama penelitian berlangsung, terdapat 43 subjek yang mengikuti seluruh tahap penelitian yang terdiri dari 16 subjek nondiabetes dan 27 subjek DMT2, sesuai dengan besar sampel minimal penelitian ini. Nilai rerata umur kelompok subjek DMT2 lebih tinggi signifikan $(\mathrm{p}=0,016)$ dibandingkan dengan kelompok nondiabetes, demikian juga dengan kadar gula darah puasa (GDP) $(\mathrm{p}=0,04)$ dan kromium serum $(\mathrm{p}=0,000)$. Nilai rerata IMT dan lingkar pinggang (LP) antara kelompok subjek DMT2 dengan 
Tabel 1. Status gizi dan parameter biokimia darah DMT2 dan nondiabetes ${ }^{1}$

\begin{tabular}{|c|c|c|c|}
\hline Variabel & $\begin{array}{c}\text { Kelompok } \\
\text { nondiabetes } \\
(n=16)\end{array}$ & $\begin{array}{c}\text { Kelompok } \\
\text { DMT2 } \\
(\mathbf{n}=\mathbf{2 7})\end{array}$ & $\mathbf{p}^{5}$ \\
\hline Umur (tahun) & $55,6 \pm 6,6$ & $60,3 \pm 5,6$ & $0,016^{*}$ \\
\hline $\operatorname{IMT}\left(\mathrm{kg} / \mathrm{m}^{2}\right)^{2}$ & $24,4 \pm 2,2$ & $23,7 \pm 2,9$ & 0,382 \\
\hline $\mathrm{LP}(\mathrm{cm})^{3}$ & $82,0 \pm 7,4$ & $85,8 \pm 8,1$ & 0,127 \\
\hline Laki-laki & $86,7 \pm 5,8$ & $89,1 \pm 7,8$ & 0,496 \\
\hline Wanita & $77,2 \pm 5,5$ & $83,9 \pm 7,9$ & $0,042 *$ \\
\hline $\mathrm{GDP}(\mathrm{mg} / \mathrm{dl})^{4}$ & $100,3 \pm 16,0$ & $133,9 \pm 61,8$ & $0,040^{*}$ \\
\hline $\begin{array}{l}\text { Kromium serum } \\
(\mathrm{mg} / \mathrm{L})\end{array}$ & $0,094 \pm 0,005$ & $0,044 \pm 0,02$ & $0,000^{*}$ \\
\hline
\end{tabular}

nondiabetes tidak berbeda signifikan $(\mathrm{p}=0,127)$, kecuali nilai LP kelompok subjek wanita DMT2 lebih besar daripada subjek wanita nondiabetes $(\mathrm{p}<0,05)$ (Tabel 1).

\section{Asupan mikromineral}

Tabel 2 menyajikan profil asupan dan tingkat kecukupan magnesium, zink, dan kromium. Berdasarkan hasil recall 2x24 jam diketahui bahwa asupan dan tingkat kecukupan magnesium pada subjek DMT2 lebih tinggi signifikan daripada subjek nondiabetes sedangkan zink dan kromium tidak berbeda signifikan antara kedua kelompok subjek $(\mathrm{p}>0,05)$. Jika dilihat dari kategori tingkat kecukupan maka diperoleh bahwa sebagian besar $(75,0 \%)$ subjek nondiabetes mempunyai asupan magnesium yang defisit ( $<77 \%$ kecukupan magnesium) sedangkan sebagian besar subjek DMT2 (63,0\%) memiliki tingkat kecukupan magnesium yang cukup. Demikian juga berdasarkan analisis asupan zink diketahui bahwa hampir semua subjek nondiabetes mempunyai asupan zink defisit (kurang) dibandingkan dengan kelompok DMT2. Secara umum, semua subjek baik nondiabetes maupun DMT2 mempunyai tingkat kecukupan kromium defisit ( $<77 \%$ kecukupan kromium).

\section{Kontribusi bahan pangan dalam total asupan mikromineral}

Asupan magnesium, zink, dan kromium didukung oleh berbagai sumber bahan pangan seperti ditunjukkan
Tabel 2. Asupan dan tingkat kecukupan $\mathrm{Mg}^{1}, \mathrm{Zn}^{2}$, dan kromium kelompok DMT2 dan nondiabetes ${ }^{3}$

\begin{tabular}{lccc}
\hline $\begin{array}{c}\text { Asupan zat gizi } \\
\text { (per hari) }\end{array}$ & $\begin{array}{c}\text { Kelompok } \\
\text { nondiabetes } \\
(\mathbf{n}=\mathbf{1 6})\end{array}$ & $\begin{array}{c}\text { Kelompok } \\
\text { DMT2 } \\
(\mathbf{n = 2 7})\end{array}$ & $\mathbf{p}^{4}$ \\
\hline Asupan & & & \\
Mg (mg) & $211,0 \pm 33,5$ & $316,1 \pm 22,4$ & $0,010^{*}$ \\
Zn (mg) & $6,2 \pm 0,8$ & $8,4 \pm 0,7$ & 0,051 \\
Kromium ( $\mu$ g) & $8,7 \pm 0,9$ & $10,8 \pm 1,3$ & 0,268 \\
Tingkat kecukupan & & & \\
Mg (\%) & $64,1 \pm 10,6$ & $95,5 \pm 6,9$ & $0,013 *$ \\
Zn (\%) & $55,4 \pm 7,9$ & $76,1 \pm 6,7$ & 0,058 \\
Kromium (\%) & $36,4 \pm 4,2$ & $47,4 \pm 6,9$ & 0,258 \\
\hline
\end{tabular}

${ }^{1} \mathrm{Mg}=$ magnesium; ${ }^{2} \mathrm{Zn}=$ zink; ${ }^{3}$ Data disajikan dalam bentuk rerata (mean) \pm SEM; SEM: standard error means; ${ }^{4}$-two independent test; *Berbeda signifikan $(\mathrm{p}<0,05)$

pada Tabel 3. Ditemukan lima jenis bahan pangan yang memberikan kontribusi paling besar pada asupan magnesium subjek nondiabetes dan DMT2, yaitu sumber karbohidrat, bahan pangan sumber protein nabati, protein hewani, buah-buahan, dan sayur. Berdasarkan uji statistik diketahui bahwa dari kelima jenis bahan pangan tersebut, protein hewani dan buah yang berbeda signifikan antara kelompok nondiabetes dengan DMT2 sebagai sumber magnesium. Sumber magnesium dari bahan pangan minyak dan kelompok pangan lainnya seperti teh, kopi, gula pasir, dan makanan jadi tidak berbeda antar kedua kelompok subjek.

Kontribusi paling besar untuk total asupan zink pada subjek nondiabetes dan DMT2 diperoleh dari jenis pangan sumber karbohidrat, protein hewani, dan protein nabati, tetapi secara statistik tidak berbeda signifikan antara kelompok nondiabetes dengan DMT2. Sumber zink dari jenis pangan sayur-sayuran juga tidak berbeda, kecuali jenis buah-buahan yang menunjukkan perbedaan signifikan antara kelompok nondiabetes dengan DMT2.

Tabel 3 juga menunjukkan bahwa kontribusi bahan pangan untuk asupan kromium pada subjek nondiabetes dan DMT2 paling besar diperoleh dari jenis pangan karbohidrat, protein hewani, protein nabati, dan buah-buahan. Kontribusi jenis pangan protein hewani signifikan lebih tinggi pada subjek nondiabetes daripada subjek DMT2 sedangkan dua jenis pangan lainnya yaitu sayur dan minyak serta kelompok lainnya tidak berbeda pada kedua kelompok subjek. Kontribusi jenis kelompok 
Ni Ketut Sutiari, dkk: Kromium serum dan asupan mikromineral pada penyandang diabetes tipe 2

Tabel 3. Kontribusi dari beberapa sumber bahan pangan (\%) untuk total asupan $\mathrm{Mg}^{1}, \mathrm{Zn}^{2}$, dan kromium pada kelompok DMT2 dan nondiabetes

\begin{tabular}{|c|c|c|c|c|c|}
\hline \multirow{2}{*}{$\begin{array}{c}\text { Sumber bahan } \\
\text { pangan }\end{array}$} & \multicolumn{2}{|c|}{ Nondiabetes } & \multicolumn{2}{|c|}{ DMT2 } & \multirow{2}{*}{$\mathbf{p}^{5}$} \\
\hline & Rerata $^{3} /$ median $^{4}$ & SD $^{3} /$ range $^{4}$ & Rerata $^{3} /$ median $^{4}$ & SD $^{3} /$ range $^{4}$ & \\
\hline \multicolumn{6}{|l|}{ Mg } \\
\hline Karbohidrat $^{3}$ & 19,9 & 8,7 & 22,7 & 9,1 & 0,336 \\
\hline Protein hewani ${ }^{3}$ & 17,7 & 11,3 & 12,2 & 6,5 & $0,049 *$ \\
\hline Protein nabati ${ }^{3}$ & 31,2 & 10,3 & 35,1 & 17,7 & 0,366 \\
\hline Sayuran $^{4}$ & 9,2 & $1,0-24,0$ & 8,9 & $1,0-73,0$ & 0,841 \\
\hline Buah-buahan $^{3}$ & 15,0 & 8,6 & 9,5 & 6,1 & $0,018^{*}$ \\
\hline Minyak dan lainnya $^{4}$ & 3,8 & $0-21,0$ & 7,4 & $0-31,0$ & 0,481 \\
\hline \multicolumn{6}{|l|}{$\mathbf{Z n}$} \\
\hline Karbohidrat $^{3}$ & 25,6 & 19,3 & 25,8 & 14,9 & 0,974 \\
\hline Protein hewani ${ }^{3}$ & 31,9 & 14,3 & 33,2 & 26,0 & 0,855 \\
\hline Protein nabati ${ }^{3}$ & 22,0 & 8,7 & 26,0 & 16,6 & 0,303 \\
\hline Sayuran $^{4}$ & 4,3 & $0-29,0$ & 5,4 & $0-70,0$ & 0,791 \\
\hline Buah-buahan ${ }^{4}$ & 8,1 & $0-33,0$ & 3,7 & $0-14,0$ & $0,030 *$ \\
\hline Minyak dan lainnya ${ }^{4}$ & 0,0 & $0-12,0$ & 0,0 & $0-18,0$ & 0,772 \\
\hline \multicolumn{6}{|l|}{ Kromium (Cr) } \\
\hline Karbohidrat $^{4}$ & 36,1 & $21,0-95,0$ & 44,6 & $4,0-59,0$ & 0,209 \\
\hline Protein hewani ${ }^{3}$ & 21,0 & 12,5 & 11,3 & 5,6 & $0,009 *$ \\
\hline Protein nabati ${ }^{4}$ & 15,2 & $2,0-45,0$ & 13,6 & $1,0-50,0$ & 0,940 \\
\hline Sayuran $^{4}$ & 4,2 & $0-23,0$ & 3,9 & $0-57,0$ & 0,555 \\
\hline Buah-buahan ${ }^{4}$ & 10,6 & $0-37,0$ & 7,97 & $0-37,0$ & 0,598 \\
\hline Minyak dan lainnya ${ }^{4}$ & 2,7 & $0-8,0$ & 22,3 & $0-59,0$ & 0,900 \\
\hline
\end{tabular}

${ }^{1} \mathrm{Mg}=$ magnesium; ${ }^{2} \mathrm{Zn}=$ zink; ${ }^{3} \operatorname{Rerata}($ mean $) \pm \mathrm{SD} ; \mathrm{SD}=\operatorname{standar}$ deviasi; ${ }^{4}$ Median $($ range $) ;{ }^{5}$-two independent test $;$ Mann Whitney test; *Berbeda signifikan $(\mathrm{p}<0,05)$; berbeda sangat signifikan $(\mathrm{p}<0,01)$

lainnya untuk asupan kromium pada subjek DMT2 cukup besar (>20\%) dan lebih tinggi dibandingkan dengan subjek nondiabetes.

\section{BAHASAN}

Penelitian menunjukkan bahwa rata-rata kelompok subjek DMT2 berusia lansia ( $>60$ tahun) dan memiliki status obesitas sentral. Diabetes mellitus tipe 2 (DMT2) merupakan penyakit yang berhubungan dengan faktor usia lansia dan obesitas (14). Umur merupakan salah satu faktor risiko penyakit DMT2. Tingginya insiden DMT2 dan prevalensi DMT2 di populasi terlihat meningkat pada usia dewasa awal dan insiden serta prevalensi meningkat pada kelompok dewasa tua (15). Seperti diketahui bahwa kelebihan berat badan (overweight) dan obesitas menjadi penanda kuat yang mendorong terjadinya diabetes dan jumlah kasus diabetes diprediksikan meningkat seiring dengan meningkatnya kasus obesitas baik di negara berkembang atau pun negara sedang berkembang (16).
Negara di Asia memiliki kasus overweight dan obesitas lebih rendah daripada negara Barat jika masih didasarkan pada nilai IMT. Terlepas dari IMT yang lebih rendah, ternyata beberapa negara Asia memiliki prevalensi diabetes sama dan bahkan lebih tinggi dari negara Barat $(17,18)$. Hal ini menggambarkan bahwa risiko DMT2 di Asia dimulai pada nilai IMT yang lebih rendah dibandingkan dengan negara Eropa.

Berdasarkan hasil penelitian, diketahui bahwa kadar GDP subjek DMT2 lebih tinggi dibandingkan dengan subjek nondiabetes (133,9 961,8 vs 100,3 $\pm 16,0)$. American Diabetes Association (ADA) menyebutkan bahwa mereka yang menderita diabetes digolongkan memiliki kontrol glikemik buruk apabila kadar GDP lebih dari atau sama dengan $130 \mathrm{mg} / \mathrm{dl}$ dan kadar hemoglobin terglikasinya (HbA1c) lebih dari 7,0\% (19). Berdasarkan penjelasan ini dapat disimpulkan bahwa subjek DMT2 dalam penelitian mempunyai kontrol glikemik yang buruk. Kontrol glikemik yang buruk dapat menjadi indikasi adanya hiperglikemia kronis pada pasien DMT2 
dan berhubungan dengan timbulnya disfungsi dan kerusakan berbagai organ terutama mata, ginjal, saraf, jantung, dan pembuluh darah (20).

Pemeriksaan biokimia darah juga menunjukkan bahwa kadar kromium serum subjek DMT2 lebih rendah hampir 50\% dibandingkan dengan subjek nondiabetes. Penelitian cross-sectional sebelumnya menemukan bahwa pasien DMT2 dewasa Pakistani mempunyai kadar kromium rendah dan ekskresi kromium urin tinggi (21). Studi review menyimpulkan bahwa metabolisme kromium berubah pada pasien diabetes, yang mana rendahnya kadar kromium pada rambut atau pun darah merupakan refleksi dari penurunan penyerapan kromium pada penyandang DMT2 (22).

Berdasarkan hasil penelitian didapatkan bahwa rerata asupan magnesium seluruh subjek berkisar 200$350 \mathrm{mg} /$ hari dan asupan magnesium pada kelompok DMT2 lebih tinggi signifikan dibandingkan dengan nondiabetes. Jika kebiasaan asupan magnesium subjek nondiabetes yang rendah dan berlangsung kronis maka dapat berisiko mengalami kekurangan magnesium. Beberapa penelitian menyebutkan bahwa kekurangan magnesium berhubungan dengan diabetes mellitus (DM) dan sindrom metabolik (23-26), meskipun mekanisme kerja magnesium sampai saat ini masih digali. Asupan magnesium subjek DMT2 pada penelitian ini lebih tinggi dibandingkan dengan hasil penelitian sebelumnya tentang asupan magnesium pada pasien rawat jalan DMT2 yang melaporkan bahwa asupan magnesium pasien rawat jalan DMT2 di RSUD Al-Ihsan Provinsi Jawa Barat berkisar antara 162 - $317 \mathrm{mg}$ dengan rerata $270 \mathrm{mg}$ /hari (10).

Seperti halnya mineral lain, magnesium diserap dalam tubuh berbanding terbalik dengan jumlah yang konsumsi. Tingkat fraksi penyerapan magnesium dalam tubuh manusia antara 30\% dan 50\% apabila rata-rata asupan magnesium 300-500 mg/hari (27). Dari penjelasan tingkat penyerapan tersebut diketahui bahwa kemungkinan asupan magnesium pada kelompok subjek DMT2 dapat diserap sekitar 30-50\% sedangkan magnesium nondiabetes diserap kurang dari $30 \%$. Penyerapan magnesium yang berkurang dapat dipengaruhi oleh fitat, oksalat dari buahbuahan, sayuran, biji-bijian, konsumsi alkohol berlebihan, dan konsumsi obat diuretik. Selain itu, ada faktor fosfor, kalsium, dan protein yang dapat menurunkan penyerapan magnesium (26). Dilihat dari faktor fitat diperoleh bahwa asupan serat subjek nondiabetes berkisar antara 1,3-481,0 $\mathrm{g} /$ hari dengan median 5,8 $\mathrm{g}$ /hari sedangkan asupan serat pangan subjek DMT2 sebesar 4,6-25,0 g/hari dengan rerata $11,9 \mathrm{~g} /$ hari. Hasil tersebut menunjukkan asupan serat semua subjek masih kurang dari AKG serat (22$33 \mathrm{~g} /$ hari) sehingga kemungkinan serat pangan tidak akan menurunkan penyerapan magnesium. Meskipun demikian, yang perlu mendapatkan perhatian yaitu subjek nondiabetes yang memiliki asupan serat melebihi AKG dan bahkan sampai lebih dari $100 \mathrm{~g} /$ hari, sebaiknya membatasi asupan serat pangan yang berlebih dengan membatasi konsumsi sumber serat (biji-bijian atau pun buah-buahan). Seperti diketahui bahwa kedua jenis pangan tersebut pada penelitian ini memberikan kontribusi cukup besar dalam asupan magnesium subjek nondiabetes. Fitat yang terkandung dalam makanan tinggi serat menyebabkan magnesium terikat pada gugus fosfat dari phytates, yang menyebabkan penurunan penyerapan magnesium. Selain itu, asupan protein rendah $(<30 \mathrm{~g}$ /hari) dan tinggi ( $>94 \mathrm{~g} /$ hari) dapat berefek dalam mengurangi penyerapan magnesium (24). Berdasarkan hasil recall diperoleh bahwa kedua kelompok subjek mempunyai rerata asupan protein sebesar 63-74 g/hari, untuk itu dapat disimpulkan bahwa jumlah asupan protein subjek tidak akan mengganggu absorpsi magnesium.

Lebih lanjut, zink merupakan salah satu jenis mineral mikro yang dikaitkan dengan kejadian diabetes dan prediabetes. Seperti yang dilaporkan dalam penelitian sebelumnya bahwa mengkonsumsi tinggi zink mungkin berkaitan dengan rendahnya risiko munculnya DMT2 pada kelompok wanita, akan tetapi hasil tersebut memerlukan konfrimasi studi-studi yang lain dan eksplorasi mekanisme potensi kerja zink pada DMT2 (8). Berdasarkan hasil penelitian ini ditemukan bahwa tidak ada perbedaan asupan zink antara kedua kelompok, meskipun nilai asupan zink DMT2 lebih tinggi daripada nondiabetes. Penemuan ini sejalan dengan penelitian sebelumnya $(28,29)$ yang membuktikan bahwa asupan zink antara diabetes dengan nondiabetes (masyarakat sehat) tidak berbeda. Namun, asupan zink subjek DMT2 pada penelitian ini lebih tinggi dibandingkan dengan asupan zink DMT2 dalam beberapa penelitian lain yaitu sebesar $8,4 \pm 0,7 \mathrm{mg} /$ hari vs $4,52-6,47 \mathrm{mg} /$ hari (28) dan 
$8,4 \pm 0,7 \mathrm{mg} /$ hari vs $6,3 \pm 0,7 \mathrm{mg} /$ hari (29). Total asupan zink akan sangat terpengaruh oleh adanya pemilihan jenis bahan pangan yang dikonsumsi (30). Disebutkan pula bahwa asupan zink berkorelasi dengan asupan protein, tergantung dari sumber proteinnya. Berdasarkan hasil analisis persentase kontribusi pangan terhadap asupan zink, diperoleh bahwa jenis bahan pangan sumber protein hewani memberikan kontribusi paling besar pada kedua kelompok subjek.

Beberapa subjek DMT2 mempunyai tingkat konsumsi zink yang tergolong defisit, bahkan hampir semua subjek nondiabetes $(87,5 \%)$ dalam studi ini juga tingkat konsumsinya defisit. Tingkat konsumsi subjek sangat dipengaruhi oleh jumlah asupan zink dan jenis bahan pangan yang dikonumsi. Seperti halnya dengan mineral lain, sistem metabolisme zink dikenal sebagai regulasi homeostatis, yang dipahami sebagai keseimbangan antara penyerapan zink dari makanan (endogen) dan ekskresi zink. Homeostatis zink tetap terjaga ketika penyerapan zink melebihi jumlah zink yang dapat dimanfaatkan tubuh, maka kelebihan zink akan dieksresikan melalui urin (30). Penyerapan zink di dalam tubuh manusia dipengaruhi oleh faktor fitat yang terkandung pada beberapa jenis pangan (kacangkacangan, sayuran atau buah) dan faktor makanan hasil fermentasi. Pemilihan varian bahan pangan yang rendah fitat seperti barley, jagung atau beras mungkin dapat meningkatkan bioavailabilitas zink dari pangan tersebut (31). Roti, sebagai salah satu makanan hasil fermentasi ternyata mampu mengurangi kadar asam fitat dan signifikan meningkatkan penyerapan zink (30). Hasil analisis recall dan SQ-FFQ menunjukkan bahwa semua jenis bahan pangan memberikan kontribusi asupan zink subjek. Bioavailabilitas zink ditentukan dari jumlah zink yang tersedia dari matriks makanan dan jumlah total zink dalam makanan $(32,33)$. Sebagai tambahan dalam pembahasan asupan zink yaitu diet rendah zink akan meningkatkan penyerapan fraksi zink tetapi menurunkan penyerapan total zink dan akan terbalik kejadiannya apabila diet yang cukup zink (34).

Sekitar tahun 1950, kromium sudah dibahas para peneliti dan disebutkan dapat memberikan manfaat bagi kesehatan diabetisi yaitu kromium mungkin mampu memperbaiki kontrol glikemik dan meningkatkan sensitivitas insulin. Namun, sampai saat ini manfaat tersebut belum konklusif dan mekanisme kerja kromium masih terus digali peneliti. Penelitian dilakukan untuk menilai status kromium subjek yang didasarkan pada nilai asupan kromium. Hasil penelitian menunjukkan bahwa asupan kromium subjek DMT2 sedikit lebih tinggi daripada subjek nondiabetes, tetapi secara statistik tidak berbeda signifikan dan semua subjek dalam penelitian belum memenuhi kecukupan kromium sesuai dengan AKG yang dianjurkan (tingkat kecukupannya $<77 \%$ ). Nilai kromium dalam AKG Indonesia pada kelompok umur di atas 50 tahun berkisar antara 20-30 $\mu \mathrm{g} /$ hari. Rerata asupan kromium pada seluruh subjek penelitian ini sebesar 8,7-10,8 $\mu$ g/hari tidak berbeda dengan hasil penelitan sebelumnya yaitu 9,3-10,2 $\mu \mathrm{g} /$ hari (29). Belum adanya data nilai kromium dalam daftar komposisi bahan pangan (DKBM) di Indonesia sehingga analisis kromium tergantung pada DKBM dari Jepang dan jenis pangan yang dikonsumsi subjek terlebih dahulu disesuaikan dengan kemiripan variasi jenis pangan yang tersedia dalam daftar. Keterbatasan dalam hal nilai kandungan kromium pada beberapa jenis pangan yang dikonsumsi oleh subjek penelitian adalah keterbatasan dalam penelitian ini. Oleh karena itu, perlu dilakukan survei analisis kandungan kromium berbagai jenis pangan dan makanan jadi di Indonesia.

Bahan makanan sumber kromium dapat ditemukan pada biji-bijian, kacang-kacangan, beberapa sayuran (misalnya brokoli dan jamur), hati, daging olahan, dan sereal siap makan $(35,36)$. Sumber kromium yang lain adalah telur, kacang kering, produk gandum, dan cokelat hitam (35). Kromium terkandung pada berbagai jenis pangan, tetapi informasi nilai kandungan kromium dalam pangan masih kurang lengkap. Hasil penelitian menunjukkan bahwa tidak ada perbedaan persentase kontribusi pada semua jenis pangan kecuali jenis pangan protein hewani. Jenis pangan hewani seperti daging ayam mampu memberikan sedikit kontribusi untuk jumlah asupan kromium bagi subjek nondiabetes sedangkan produk makanan khusus diabetes (masuk dalam kelompok pangan lainnya) ikut memberikan kontribusi besar dalam jumlah asupan kromium subjek DMT2. Pada penelitian ini, produk makanan khusus bagi penyandang diabetes yang dikonsumsi subjek DMT2 seperti produk susu dan gula khusus diabet yang mengandung kromium. 
Nilai asupan magnesium, zink, dan kromium, serta kadar kromium serum telah diukur dan dianalisis dalam penelitian ini. Namun, penelitian ini memiliki keterbatasan dalam penilaian kadar ekskresi magnesium, zink, dan kromium dalam urin, pemeriksaan kadar magnesium dan zink dalam serum, serta nilai kandungan kromium beberapa jenis bahan pangan atau makanan di Indonesia yang dikonsumsi subjek.

\section{SIMPULAN DAN SARAN}

Kromium serum DMT2 lebih rendah dibandingkan dengan nondiabetes dan hal ini didukung pula dengan asupan kromiumnya yang rendah. Jenis mineral magnesium, zink, dan kromium merupakan jenis mineral yang terkait dengan perbaikan kontrol glikemik dan resistensi insulin. Subjek DMT2 dan nondiabetes di Kota Denpasar mempunyai asupan magnesium yang cukup sesuai dengan kecukupan magnesium yang dianjurkan sedangkan asupan zink dan kromium subjek DMT2 dan nondiabetes tidak berbeda dan tergolong kurang dari nilai kecukupan zink dan kromium yang dianjurkan.

Saran untuk penelitian lebih lanjut sebaiknya melakukan pengukuran mineral magnesium, zink, dan kromium pada urin dan serum untuk memberikan gambaran status mineral magnesium, zink, dan kromium pada penyandang DMT2 dan mungkin dapat menggambarkan nilai bioavailabilitas mineral. Saran kepada pemangku kebijakan yaitu sebaiknya melakukan kajian kandungan kromium setiap bahan makanan atau makanan khas daerah di Indonesia guna memperkaya kandungan gizi dalam Daftar Komposisi Bahan Pangan di Indonesia.

\section{RUJUKAN}

1. American Diabetes Association. Standards of medical care in diabetes. Diabetes Care 2015;39(1):s1-s119.

2. Perkumpulan Endokrinologi Indonesia. Konsensus pengelolaan dan pencegahan diabetes melitus tipe 2 di Indonesia. Jakarta: Perkumpulan Endokrinologi Indonesia; 2011.

3. Nsonwu AC, Usoro CAO, Etukudo MH, Usoro IN. Serum and urine levels of chromium and magnesium in type 2 diabetics in Calabar, Nigeria. Mal J Nutr 2005;11(2):13342.
4. Praveeena S, Sujatha P, Sameera K. Trace elements in diabetes mellitus. J Clin Diagn Res 2013;7(9):1863-5.

5. Nsonwu AC, Usoro CAO, Etukudo MH, Usoro IN. Glycemic control and serum and urine levels of zinc and magnesium in diabetics in Calabar, Nigeria. Pak J Nutr 2006;5(1):75-8.

6. Kobayashi Y, HattoriM, Wada S, Iwase H, Kadono M, Tatsumi H, et al. Assessment of daily food and nutrient intake in Japanese type 2 diabetes mellitus patients using dietary reference intakes. Nutrients 2013;5:2276-88.

7. Walti MK, Zimmermann MB, Spinas GA, Jacob S, Hurrel RF. Dietary magnesium intake in type 2 diabetes. Eur J Clin Nutr 2002;56:409-14.

8. Sun Q, Van Dam RM, Willett WC, Hu FB. Prospective study of zinc intake and risk of type 2 diabetes in women. Diabetes Care 2009;32(4):629-34.

9. Vashum KP, McEvoy M, Shi Z, Milton AH, Islam MD, Sibbritt D, et al. Is dietary zinc protective for type 2 diabetes? Results from the Australian longitudinal study on women's health. BMC Endocrine Disorders 2013;13(40):1-8.

10. Faradhita A, Handayani D, Kusumastuty I. Hubungan asupan magnesium dan kadar glukosa dadrah puasa pasien rawat jalan diabetes mellitus tipe 2. Indonesian Journal of Human Nutrition 2014;1(2):71-88.

11. Cochran WG. Sampling technique. New York: John Willey and Son; 1982.

12. Ghosh D, Bhattacharya B, Mukherjee B, Manna B, Sinha $\mathrm{M}$, Chowdhury S, et al. Role of chromium supplementation in Indians with type 2 diabetes mellitus. J of Nut Biochem 2002;13:690-697.

13. Gibson RS. Principles of nutritional assessment. New York: Oxford University Press; 2005.

14. Ajibola RS, Ogundahunsi OA, Soyinka OO, Ogunyemi EO, Odewabi AO. Serum chromium, molybdenum, zinc and magnesium levels in diabetes mellitus patients in Sagamu, South West Nigeria. Asian Journal of Medical Sciences 2014;6(2):15-9.

15. Chen L, Magliano DJ, Zimmet PZ. The worldwide epidemiology of type 2 diabetes mellitus - present and future perspectives. Nat Rev Endocrino 2012;8:228-36.

16. Hu FB. Globalization of diabetes the role of diet, lifestyle and genes. Diabetes Care 2011;34:1249-57.

17. Huxley R, James WP, Barzi F, Patel JV, Lear SA, Suriyawongpaisal $\mathrm{P}$, et al. Ethnic comparisons of the crosssectional relationships between measures of body size with diabetes and hypertension. Obes Rev 2008;9(1):53-61.

18. Chan JC, Malik V, Jia W, Kadowaki T, Yajnik CS, Hu FB, et al. Diabetes in Asia: epidemiology, risk factors, and pathophysiology. JAMA 2009;301(20):2129-40.

19. American Diabetes Association. Diagnosis and classification of diabetes mellitus. Diabetes Care 2011;1:S62-S69. 
20. Centers for Disease Control and Prevention. National diabetes fact sheet 2011. [series online] 2011 [cited 2016 Jan 20]. Available from: URL: https://www.cdc.gov/ diabetes/pubs/pdf/ndfs_2011.pdf.

21. KaziT, Afridi H, Kazi N, Jamali M, Arain M, Jalbani N, et al. Copper, chromium, manganese, iron, nickel, and zinc levels in biological samples of diabetes mellitus patients. Biol Trace Elem Res 2008;122(1):1-18.

22. Kaur B, Henry J. Micronutrient status in type 2 diabetes: a review. Adv Food Nutr Res 2014;71:55-100.

23. Guerrero-Romero F, Rodríguez-Morán M. Hypomagnesemia, oxidative stress, inflammation, and metabolic syndrome. Diabetes Metab Res Rev 2006;22:471-6.

24. Guerrera MP, Mao JJ, Volpe SL. Therapeutic uses of magnesium. Am Family Phys 2009;80:157-62.

25. Davì G, Santilli F, Patrono C. Nutraceuticals in diabetes and metabolic syndrome. Cardiovasc Therapeut 2010;28:21626.

26. Volpe SL. Magnesium, the metabolic syndrome, insulin resistance and type 2 diabetes mellitus. Crit Rev Food Sci Nutr 2008;48:293-300.

27. Volpe SL. Magnesium. In: Erdman JWJ, Macdonald IA, Zeisel SH, editors. Present knowledge in mutrition tenth edition. Iowa USA: Wiley Blackwell (John Wiley \& Sons); 2012.

28. Winokan MAC, Sayogo S, Tarigan THE. Serum zinc level in type 2 diabetes and its association with zinc, animal protein, phytate and dietary fiber intakes. Maj Kedokt Indon 2010;60(2):60-6.
29. Unjiati, Wirjatmadi B, Adriani M. Chromium and zinc level of ptients with type 2 diabetes and non-diabetes. Biochem Physiol 2015;S5(10):1-5.

30. Holt RR, Uriu-Adams JY, Keen CL. Zinc. In: Erdman JWJ, Macdonald IA, Zeisel SH, editors. Present knowledge in mutrition tenth edition. Iowa USA: Wiley Blackwell (John Wiley \& Sons); 2012.

31. Lonnerdal B, Mendoza C, Brown KH, Rutger JN, Raboy $\mathrm{V}$. Zinc absorption from low phytic acid genotypes of maize (Zea mays L), barley (Hordeum vulgare $\mathrm{L}$ ), and rice (Oryza sativa $\mathrm{L}$ ) assessed in a suckling rat pup model. J Agric Food Chem 2011;59:4755-62.

32. Hambidge KM, Miller LV, Westcott JE, Seng X, Krebs NF. Zinc bioavailability and homeostasis. Am J Clin Nutr 2010;91(5):1478S-83S.

33. King JC. Does zinc absorption reflect zinc status? Int J Vitam Nutr Res 2010;80:300-6.

34. Chung CS, Stookey J, Dare D, Welch R, Nguyen TQ, Roehl R, et al. Current dietary zinc intake has a greater effect on fractional zinc absorption than does longer term zinc consumption in healthy adult men. Am J Clin Nutr 2008;87(5):1224-9.

35. Byrd-Bredbenner C, Beshgetoor D, Moe G, Berning J. Wardlaw's prespectives in nutrition eighth edition. New York: McGraw-Hill; 2009.

36. Nielsen FH. Manganese, molybdenum, boron, chromium, and other trace elements. In: Erdman JWJ, Macdonald IA, Zeisel SH, editors. Present knowledge in mutrition tenth edition. Iowa USA: Wiley Blackwell (John Wiley \& Sons); 2012. 